\title{
Construction of ESP Teaching System
}

\author{
Fangpeng Gai \\ School of Foreign Studies, Shandong Jiaotong University, China
}

\begin{abstract}
This article explores into the mode of fostering interdisciplinary talents' practical English skills in the universities of science and engineering under the background of internationalization of higher education and economic globalization. On the basis of discussing the current situation of ESP teaching and the investigation of teaching demand, the author of this paper analyzes how to construct the ESP teaching system from the four aspects of teaching materials, teaching methods, teacher training and evaluation. The creation of personalized teaching materials and multiple activities can help all students enjoy the pleasure of learning and make students really feel the charm of English.
\end{abstract}

Index Terms - ESP, teaching system, construction

\section{INTRODUCTION}

With the internationalization of higher education and the economic globalization, the international exchange and communication has more frequently happened, so the requirement for college students' English ability has been gradually turned to the promotion of the ability to solve professional problems in English. Therefore, how to construct a new College English teaching system of training applied talents with high English proficiency has become an urgent topic to the English teachers in the universities of science and engineering.

Nowadays, the main criticism faces with College English teaching is that the teaching content is divorced from the students' professional knowledge and daily life. Our English teaching is still the exam-oriented teaching mode, which has been existing from primary schools till senior middle schools. The repetition in certain content and the sustainable focus on the basic communication skills cause the students' low enthusiasm in English learning and motivation.

In the year of 1987, Hutchinson \& Waters firstly proposed that EFL (English as Foreign Language) consist of two branches: GE (General English, which is also called EGP) and ESP (English for Specific Purposes). Later, Jordan (1997) further divided ESP into EAP (English for Academic Purposes) and EOP (English for Occupational Purposes). And there are also some other scholars who have discussed their opinions on the divisions of ESP.

As to the difference and relationship between EGP and ESP, EGP/GE refers to English for GeneralPurpose, which includes English language skills of reading, listening, speaking, writing and translation. The main purpose of EGP is to develop learners' basic English language skills. ESP, the abbreviation of "English for specific/special purposes", which originated in the 1960s, is based on the learner's specific purpose and needs of the learners. It is a course referring to a specific profession or discipline related to English. Halliday, Mcinfash and Strevens define ESP as: "English for civil servants; for policemen; for officials of the law; for dispensers and nurses; for specialists in agriculture; for engineers and fitters". In one sentence, ESP is used in a specific field by professionals.

It is the combination of EGP teaching with one aspect of professional knowledge or a certain subject, which is the inevitable development of College English teaching. According to our National medium-and long-term education reform and development Planning Framework (2010-2020), only by extending the teaching of EGP to ESP, can we cultivate international talents with global vision, familiarity with international rules, participation in international affairs and International Competition.

The construction of College English teaching system in universities is essentially a topic of how universities keep up with our social development. Historically, the university's social service function has shifted from passive response to active adaptation, which means universities should instruct the students to serve the society with their knowledge. Under this circumstance, some scholars put forward that College English should transit from EGP to ESP.

\section{Current Situation of ESP Teaching Research in China}

In recent years, Chinese scholars and teachers have done a lot in ESP research. Liu Wenjun (2012), LAN (2013), Fu Qiang (2014) and so other scholars explored ESP curriculum design, teaching management, teacher training and teaching practice according to the different specialities of their universities respectively. Zhu Meiping and Shen Yuewen (2010) introduced the problems encountered in ESP teaching in Beijing Foreign Studies University and discussed the strategies. Liu Mei (2013) probes into College English teaching based on ESP course system, and proposes a continuum model of College English teaching in five stages.

Some other scholars studied different teaching methods. Zhou Dongbiao (2014) and Li Shujun (2014) discussed the application of Constructivist teaching mode and thematic teaching mode in college English teaching in application-oriented institutes. Cui Chuanming and Shi Lei (2011) discussed Task-based English teaching and displayed its classroom practice. Nan Hongyan (2006), He Yue (2012) respectively proposed the network plus interaction and 
classroom display method and teaching models.

The above-mentioned studies have probed into the establishment and orientation of college ESP course and teaching methods from different perspectives in universities. The studies provide us with the practical and methodological guidance of the ESP teaching, and the researches have done a lot on the difficulties in classroom teaching from the theoretical level. However, there are some limitations in the existing research: firstly, how to define the teaching orientation of ESP course in different types of colleges and universities, especially in the aspects of teaching material construction, teaching content, evaluation methods and teacher training. Secondly, there is still a lack of empirical research on the research of ESP course in Engineering colleges.

Meanwhile, there are also some other factors that affected the ESP teaching in our country. Because of the long absence of theoretical research, ESP teaching system has been in a chaotic state for many years, in our universities, highlighting the The lack of clarity in teaching purposes and the absence of two of syllabus.

Although there are numerous scholars have done research on ESP in our country, but our theoretical research on it has not been emphasied. To make ESP develop in universities teaching, firstly we should strengthen ESP theoretical research, to find the effective way of improving ESP teaching method and practice it, and then our ESP teaching can really make great progress. All in all, the transition from EGP to ESP needs a lot of practice.

From the 1960s, ESP research abroad has established a relatively complete system, and there are representative scholars and works at every stage of the ESP development, but the concept of ESP and division method have not been agreed. In the teaching practice, many colleges and universities in Britain and America aim at teaching the language knowledge and skills needed for academic English before the foreign students contact the specific course, which is mainly to help learners to improve the language comprehensive ability and academic writing, including written assignments, classroom discussions and presentations, and paper writing skills, to help foreign students to get through the difficulties of listening to English lectures and courses before class. At the same time, in many other countries and regions, such as Singapore, Italy and Hong Kong of China, ESP curriculum design, textbook preparation, outline formulation are complete, and ESP teaching has gradually come into the mainstream in order to provide language ability for foreign exchange and cooperation. However, in the ESP teacher training, most countries have not established the system to train professional ESP teachers.

\section{SURVEY ON ESP LEARNING NEEDS}

Before the implementation of College English Curriculum Requirements, our College English is mainly General English, whose purpose is to help students develop proficient language skills. With the rapid development of China's economy and increasingly frequent international exchanges in recent years, our society put forward higher requirements on the comprehensive English ability for College students. College English teaching has shifted its focus to improve students' English comprehensive practical ability. Meanwhile, College English credits are greatly compressed under the new situation, which decreased from the original 16 credits to 12 credits. It is beneficial for college students to have more energy to learn some other English courses so as to promote the overall English proficiency.

The author of this study randomly investigated some students of different majors so as to know their evaluation of the current College English learning and their expectations and attitudes to English learning. Some graduates were also interviewed to get information about the practical use of English in real life. The results are as follows:

A. Students'Understanding of the Current College English Learning and the Motivation and Attitude to ESP Learning

More than half of the students interviewed think that through the previous 10-odd-years English learning, they have grasped some basic skills of English listening, speaking, reading and writing, and mastered the basic phonetic grammar knowledge and a considerable number of words. In the following years in universities, they hope the English teachers can teach them some knowledge related to their future study and work. They believe they should continue with EGP learning, some basic English skills still need strengthening so as to further consolidate the foundation. In the second year, basic ESP teaching should be the aim in order to meet the different needs of various professionals, whose main content is to teach how to use the EGP and ESP knowledge to achieve professional proficiency in certain fields.

The main motivation for most students to learn ESP is the need for work in the future, and few students think that the only motivation of their ESP learning is to pass the final exam to get credits. Their motives belong to instrumental motives, that is, to learn English well so to find a good job for the future personal development. This is in line with the ESP characteristic, namely, the goal is clear, the pertinence is strong and the practical value is high. More than fifty percent of the students think that learning ESP is to learn more about English as a tool, which also shows that most students realize the importance of English as a skill to professional learning.

In order to continue to improve their English, most students are willing to learn this course. They think it is necessary to learn ESP courses, and they are interested in it and confident to learn ESP well. They are aware of the importance of ESP, believing that more and more jobs in the future will combine English with the working fields, and they have a positive attitude towards learning such courses.

\section{B. ESP Learning Objectives}

Most students hope to mainly improve their listening and speaking ability through ESP courses. The results of this 
investigation are related to the target orientation of their professional English teachers. Due to the lack of English teaching background, professional English are instructed by the Professional teachers, who basically follow the teaching theory of grammar translation. They pay attention to the vocabulary, reading and translation. The lack of the English teaching methods lead to their difficulty in helping students practice listening and speaking, and so most students expect to improve their communicative competence in ESP with the help of English teachers. Most students hope that through the ESP course learning can exchange professional information in English and read English professional material, which illustrates that the students want to learn practical English skills for their future professional work.

Many students believe that the content of the ESP learning should be closely relevant to the their majors, which is in line with the definition of ESP presented by Hutchinson and Waters (1984), who proposed that ESP should be related to a specific profession or occupation.

Most students hope that in the ESP class, teachers and students could communicate more frequently and do some real situational dialogue practice, rather than just listening to the teacher to explain and translate the text. So the teachers must create English situational atmosphere in English class. If teachers use Chinese in ESP teaching, the effect is equivalent to the grammar translation method teaching, which is difficult to achieve the goal of English communication.

After interviewing some graduates, we find most graduates think that the professional comprehensive ability and proficient ESP ability can be beneficial to their profession. Therefore, College English should follow the social needs to strengthen students' basic ESP literacy to meet the social needs.

\section{ESPTEACHING SYSTEM CONSTRUCTION}

The construction of ESP teaching system includes teaching material, teaching methods, teacher training and teaching evaluation.

\section{A. Teaching Material Construction}

Due to various specialities and different English levels of the students, College English teachers should choose different teaching materials of ESP course for students. The application of ESP teaching materials should focus on the transition from College English to professional English, highlighting the language skills training and aiming at using English to obtain professional knowledge.

For example, in Printing English, the lexical part of the textbook should analyze the lexical features of Printing English in terms of common vocabulary, interdisciplinary vocabulary and professional vocabulary, so as to make the students master the vocabulary usage.

(1) Common words

There will always be some common core content in language, such as the following commonly used vocabulary in printing and packaging,: paper, paperboard, material, plastics and so on. Some are not commonly used in daily life, but are commonly used in the printing industry, such as corrugated paper, Bristol paper (high quality paper, glossy paper), newsprint, cover paper, Kraft/brown paper, foil paper.

(2) Interdisciplinary vocabulary

Everything in the world is interrelated, the same with professional disciplines. Many disciplines need to be supported or based on other disciplines, and the printing profession is no exception. For example, as the main raw material of printing, the physical properties of paper determines the quality of ink color, which has an important impact on the the quality of the product printing. Understanding the physical properties of paper can guarantee the quality of printed products. Similarly, printing technology can not be separated from chemical knowledge. For example, printing and chemistry are inextricably linked. As an important branch of natural science, chemistry is a discipline that specializes in the study of the structure, nature and application of matter. In the printing technology and production, it involves many branches of chemistry, such as physical chemistry, organic chemistry, inorganic chemistry, analytical chemistry, dye chemistry and so on.

For example, in this sentence: Paperboard has the following advantages: recyclable and biodegradable; Produced with different degrees of opacity.

Some of the terms in this sentence may appear in chemistry, physics, biology, materials and other disciplines. And due to their relevance to these professions, many of the relevant words are frequently found in printed professional English materials, such as recyclable, biodegradable, opacity, and so on. They are more common vocabulary, its meaning rarely change with the subject and professional.

Today the world's printing technology is developing rapidly, if someone wants to learn about the latest industry developments in the foreign countries and to master the advanced technology, he/she must have the ability to read professional materials in English. The printing major students are the future practitioners and technicians in this industry, their professional English level directly affects the degree of international exchange with foreign counterparts. Therefore, English and professional needs should be combined to train talents in the course of ESP construction.

(3) Professional vocabulary

There are two types of professional vocabulary in the field of printing: one is the specialization of common vocabulary and the other is vocabulary solely to the printing-related professional.

The specialization of common vocabulary refers to the new professional meaning and special pragmatic function in 
the field of printing. For example: makeup, ordinary words can be said "cosmetics", while in printing terms, it means "imposition". Substance, a common word for "material" in daily life, but in printing professional terminology, the expression refers to "paper quantitative; a standard weight of paper". Another expression "Platebed" are everyday words in daily life and are closely related to our life. However, in the jargon of printing, the expression refers to a device, flat-pressed or round-flattening printing machine for the installation of a printing plate platform. These words are common words in our daily life, but when diverted to the printing professional English, special meanings derive.

In addition to these single words, some combination of two or more words is produced in printed English. According to statistics, the synthetic terminology of EST constitutes the 80-90 percent of all the terms. In most cases, one can infer its meaning literally, such as plastic duplicate plate (plastic version), Ink-water balance (balance between water and ink), printing trouble (printing failure). The meaning of only a small number of synthetic words is far from the literal meaning, such as out of the Register (Misregister) and so on.

The other case is professional vocabulary only used in the field of printing, which is usually defined but narrow in meaning scope, often with only one interpretation in the specific profession. These professional terms must be translated in accordance with the specifications of the printing profession. Such words can be divided into three categories:

General professional vocabulary in the field of printing, such as: lithography (lithographic printing), laminating (laminating), perforating (punching), etc.

Abbreviation: The development trend of modern science and technology English style is to simplify the expression of words, and to use abbreviations to accord with the development trend of simplicity. Therefore, a large number of abbreviations can be seen in the professional English vocabulary of any subject. Abbreviations in terminology are commonly used in the professional and technical ranks, such as: SBS (solid bleached sulphate, copper paper jam), WCC (waxed corrugated containers, surface wax corrugated box), CCNB (clay coated news back, a recycled material made with gray matter coating cardboard), cckb (Clay Coated Kraft back, a white board cardboard), CCWB (clay coated white back, gray core cardboard). These words are often summed up in the use of words, it will be easy to remember: $\mathrm{cc}=$ clay coated,

Directly borrowed loanwords: Collotype printing was originally mainly for the printing of prints, invented by the Germans in 19th century and was introduced into China in the early Qing Dynasty. As a result of the use of gelatin in the production process, so the Greek word "Collo" was used to mean glue (gum). In fact, the term literally means "glass plate printing".

These terminologies are best used to establish a printing professional corpus. As a professional field of English, its terminology has its own meaning. Since the United States Brown corpus was built in the 1960s, with the development of computer technology, corpus has been widely used in all aspects of language research. One of the achievements of corpus research is the context. Its KWIC technology provides contextual words for the search of keywords, and the word is shown to the reader. Because the corpus is the language material which appears in the real language use, its context may provide the translator with the reliable understanding information, so it plays a more and more important role in the modern linguistics research. Based on the above advantages, the printing industry's technical practitioners should jointly develop the printing professional English corpus, which will play an extremely important role in the teaching of English for printing majors.

\section{B. Teaching Methods}

According to the characteristics of engineering students and different teaching contents, different methods can be used in ESP teaching, such as immersion, task-based approach, communicative method and so on, adhering to the principle of practicing as the center. Through the diversified design of teaching methods, ESP teachers can help to improve the students' interest and practicality of classroom teaching. Using the methods of real communication, written writing and situational simulation to test the students' learning effect, and using self-evaluation and peer evaluation to measure the students' English practical ability can arouse students' interest and enthusiasm.

According to the characteristics of ESP teaching, it emphasizes the learner-centered organization according to learners' needs, and the cultivation of the students' ability of language application. Therefore, teachers should pay attention to the classroom organization and classroom teaching in the teaching process. In ESP teaching, discussion, writing and oral expression are considered as the three most difficult learning skills. These skills are the ability that people can take with them anywhere to help them cope with the new situation. The foreign ESP teaching pays more attention to the combination of the comprehensive skills training and the sub-item skills training simultaneously in the teaching practice.

In Chinese ESP teaching, the traditional language skill-centered and the teaching-centered are still deeply rooted. Through the investigation of professional English class, we can see most teachers are still using the traditional method of grammar translation, while neglecting the communicative competence. Therefore, we urgently need to explore effective teaching methods. ESP teaching should establish a student-centered teaching method according to the students' needs. The emphasis should be on cultivating students' pragmatic competence, and teachers should lay emphasis on the combination of language knowledge and language use in teaching. Attention should be paid to the process of developing the students' ability to use language in activities. That is, the activities including information conversion, summarizing the gist of the article, drawing conclusions, reasoning, problem solving and so on should be the goal. The 
teacher also should give feedback and evaluation to the students. If the knowledge and skills learned by the students are only related to individual decision-making, instead of getting recognition or criticism, then it is not conducive to the improvement of the students' interest in learning. In this way, teachers and students are both in interactive state in the process of activities, which can enhance language acquisition and professional knowledge. Therefore, we should pay attention to the teaching method of ESP, so that the teaching practice can be in line with the characteristics of students and professional characteristics of teaching methods.

\section{Teacher Training}

The level of teachers' ability directly determines the teaching efficiency of ESP, so the quality of the teachers is the most important factor in the teaching. Nowadays, many universities are faced with the same problem in ESP teaching, that is, teachers are not professional enough. The College English teachers have a solid basic knowledge, but lack expertise in the field; While the professional teachers have rich professional knowledge, but lack language skills and English teaching methods and experience, so both cannot meet ESP teaching requirements. In order to improve the teaching quality of ESP, combining the two kinds of teaching resources and implementing cooperative teaching would be a good choice, that is, relating the English proficiency of College English teachers with expertise of professional teachers, the cooperation of the teachers can help complete the compilation of teaching materials, the design of instructional tasks and the selection of teaching methods, so as to improve teaching quality to a large extent. I believe that through these efforts, the teachers will be fully qualified for the teaching of ESP.

Teachers who instruct ESP courses must undergo training, which should include two aspects: language training (language improvement) and professional training (professional development). The former refers to the improvement of language skills, and the latter refers to mastering the knowledge structure, teaching method and the stylistic features of the professional English taught.

In the specific teacher training, the following issues should also be paid attention to:

(1) ESP teachers should establish a correct attitude to the transformation from EGP to ESP. Some teachers are forced and unwilling to work for ESP teaching, and some English teachers are not very knowledgeable or interested in the new professions involved, and the lack of self-confidence and the spirit of active study in teaching also would lead to failure. Therefore, when choosing ESP teachers, we should respect the teachers' wishes and choose those who are willing to be engaged in ESP teaching. At the same time, these teachers should be made aware that they are facing the challenge of learning new subjects, and only with a positive attitude and full enthusiasm can they will be competent for teaching ESP as well as possible.

(2) The change of teacher's role. In the traditional English teaching, most teachers are just lecturers, students are only passive recipients. But according to the characteristics of ESP teaching, teachers should not only become good lecturers, but also should be a good guide to motivate students to learn, be a walking dictionary for the students and be the participants in the classroom activities. In a word, ESP teachers should have a good understanding of the multi-level teacher's role, which is also a prerequisite for ESP teachers.

\section{Teaching Evaluation}

The traditional teaching evaluation emphasizes the quantitative score and the summative evaluation method, which not only neglects the guiding and stimulating function of teaching evaluation, but also deemphasizes the evaluation of students' thinking ability, problem solving ability, mutual cooperation and communication ability, which leads to the unilateral development of students. ESP learning is prepared for the future use in the industry. According to the individual differences and learning needs of students, to construct a variety of evaluation methods to measure the teachers' teaching and students' learning results comprehensively throughout the whole process, is an effective way to improve the ESP teaching. Therefore, ESP teaching evaluation should adopt the model of formative evaluation and summative evaluation. The formative evaluation combines with the students' situational practice ability and professional language knowledge acquisition in order to promote the study and improve the learning efficiency; Meanwhile, the teachers can use formative evaluation to analyze teaching effect, arrange teaching progress and teaching method rationally to improve teaching efficiency.

The authenticity standard can not be neglected in ESP curriculum evaluation. Creating a real context is an effective way to improve the students' ESP learning. The purpose of ESP course evaluation is to test the learners' capacity in the real language environment. Therefore, the ESP evaluation performer should understand what kind of language ability the ESP real user should have in the real environment, what kind of professional knowledge should be mastered, what language tasks to complete. Through such reliable evaluation, the students can realize the gap between their study and needs. There is no doubt that adherence to the principle of authenticity can guarantee the validity of ESP course evaluation. If conditions permit, in the ESP course evaluation, some industry evaluation should be introduced because the industry employers have more specific standards and requirements for the ESP talents. Only the evaluation based on the standards of the enterprises and on the ability or quality of the relevant vocational posts can be the scientific evaluation mechanism for ESP learners.

\section{CONCLUSION}


As the designers of ESP teaching activities, teachers should make clear the importance of the demand analysis in the ESP course, investigate the students' learning needs, select suitable teaching material, arrange teaching process and choose comprehensive teaching evaluation methods so to try to meet the students' needs in ESP learning.

ESP teachers should be very cautious at defining students' learning needs, setting teaching objectives and selecting teaching materials. Learning needs is a prerequisite for curriculum design, each course should be designed to take into account the needs of students so that what they want to learn and should learn can be clear. According to the result of the requirement analysis, teachers can set up the teaching goal, arrange the teaching plan, and let the students reach their goal progressively. In this process, the choice of teaching materials must be based on the students' situation, curriculum objectives, course contents and so on.

Then the teachers can arrange the teaching process. Choosing a teaching method that is both suitable and welcomed by the students needs careful investigation and thinking. In the teaching mode, teachers should be able to arrange the teaching flexibly and the syllabus can be fine-tuned when appropriate to motivate learning. Meanwhile, ESP teachers should adopt the pluralistic teaching method for the students so that respect for the personality can be truly realized. Teachers should set up a pluralistic activity scene according to the theory of multiple intelligences, so that all students can enjoy the joy of learning and experience the charm of English.

Curriculum evaluation is an inseparable part of all the curricula. It is the step to check whether the students have acquired what should be grasped, to test teachers' teaching, curriculum arrangements and the degree of completion of teaching objectives. It can help teachers find the defects in the teaching process and the gap between the teaching goals and students' learning results. The evaluation guides the teachers to make adjustments to future teaching. But in the ESP teaching evaluation, the evaluation of students' achievement should not be judged only by the final paper. The teachers should take into account the students' daily behavior, their response in class and participation in the learning process.

The feasibility and the scientificity of setting up ESP teaching system between EGP and professional English teaching depend a lot on the College English teachers to carry on the massive creative work, because there is no ideal model for our reference. ESP also belongs to English language, so we should probe into the common part between EGP and ESP to find out something we can make good use.

All in all, in the establishment of ESP curriculum system, we should pay attention to all the steps in the teaching process, making good use of each individual's intelligence, applying multiple teaching methods.

The study of ESP course has realistic significance. ESP teaching is an inevitable trend as a result of China's opening-up, international exchange and education reform. Although it is just a bud and we are still faced with many problems and difficulties in its teaching, we have a lot of expectations on it if we can carefully analyze the current situation, establish an effective method of ESP teaching and explore a suitable way to improve the students' ESP learning.

\section{REFERENCES}

[1] Hutchinson, T., \& Waters, A. (1987). English for Specific Purposes, a Learning-Centered Approach. Cambridge: Cambridge University Press.

[2] Halliday, A. Mcinfash and P. Strevens. (1964). The Linguistic Sciences and Language Teaching. London: Longman.

[3] Jordan, R. R. (1997). English for Academic Purposes: A Guide and Resource Book for Teachers. Cambridge: Cambridge University Press.

[4] Liu Yunqing. (1999). On college English Teaching. Beijing: Foreign language Teaching and Research Press.

[5] Ministry of Education of the People's Republic of China. (2007). College English Curriculum Requirements, Beijing: Tsinghua University Press.

[6] National medium-and long-term education reform and development Planning Framework. (2010-2020). http://old.moe.gov.cn//publicfiles/business/htmlfiles/moe/moe_838/201008/93704.html. (accessed 23/08/2017).

Fangpeng Gai was born in Yantai, China in 1979. He received his master degree from Shandong University, China in 2012.

$\mathrm{He}$ is currently an associate professor in the School of Foreign Languages, Shandong Jiaotong University. His research interests include English teaching and legal English. 